\title{
Effects of system parameters and inorganic salts on the photodecolourisation of textile dye Reactive Blue 19 by $\mathrm{UV} / \mathrm{H}_{2} \mathrm{O}_{2}$ process
}

\author{
Miljana D Radović ${ }^{1}$ Jelena Z Mitrovićc, Danijela V Bojić1, Milan D Antonijević ${ }^{\text {, }}$ Miloš M Kostić1, Rada M Baošić3, \\ Aleksandar Lj. Bojićl* \\ 'Department of Chemistry, Faculty of Science and Mathematics, University of Niš, Visegradska 33, 18000 Niš, Serbia \\ ${ }^{2} S$ Chool of Science, University of Greenwich, Chatham Maritime, Kent, ME4 4TB, UK \\ ${ }^{3}$ Faculty of Chemistry, University of Belgrade, Studentski trg 12, 11000 Belgrade, Serbia
}

\begin{abstract}
The photodecolourisation of textile dye Reactive Blue 19 (RB 19), an anionic anthraquinone dye of the reactive class, was investigated using $\mathrm{UV}$ radiation in the presence of $\mathrm{H}_{2} \mathrm{O}_{2}$ in a batch photo-reactor with low-pressure mercury lamps. The effects of the system parameters: initial $\mathrm{pH}$, initial dye concentration, concentration of peroxide and radiation intensity, as well as the presence of salts, $\left(\mathrm{NaCl}, \mathrm{Na}_{2} \mathrm{SO}_{4}, \mathrm{NaNO}_{3}, \mathrm{NaH}_{2} \mathrm{PO}_{4}\right)$ on dye decolourisation was examined. Increasing the initial $\mathrm{pH}$ resulted in an increase in decolourisation efficiency. Results showed that with an increase of dye concentration from 10 to $100 \mathrm{mg} \cdot \ell^{-1}$, the efficiency of the process decreases. The highest decolourisation rates were noted at $\mathrm{H}_{2} \mathrm{O}_{2}$ concentrations of approximately $30 \mathrm{mmol} \cdot \ell^{-1}$. The increase of radiation intensity from 730 to $1950 \mu \mathrm{W} \cdot \mathrm{cm}^{-2}$, linearly increases decolourisation efficiency. The inorganic ions investigated have inhibiting effects on $\mathrm{RB} 19$ decolourisation by the $\mathrm{UV} / \mathrm{H}_{2} \mathrm{O}_{2}$ process with inhibition intensities in the following order: $\mathrm{H}_{2} \mathrm{PO}_{4}^{-}>\mathrm{NO}_{3}^{-}>\mathrm{SO}_{4}{ }^{2-}>\mathrm{Cl}^{-}$. This study has shown that the $\mathrm{UV} / \mathrm{H}_{2} \mathrm{O}_{2}$ process is a promising technology for degradation of RB 19 in water and wastewater.
\end{abstract}

Keywords: $\mathrm{UV} / \mathrm{H}_{2} \mathrm{O}_{2}$ process, Reactive Blue 19, decolourisation, inorganic salts

\section{INTRODUCTION}

In the textile industry, the dyeing process produces large quantities of wastewater with intense colouration that has to be eliminated before release into the environment. Wastewaters from the textile industries contain different types of synthetic dyes, which are mostly toxic, mutagenic and carcinogenic (Zollinger, 2003; Song et al., 2008). There are many structural varieties of dyes, such as azo, anthraquinone, phthalocyanine, direct, reactive, dispersive, acid, basic, neutral and metal complexed. The three most commonly used groups of dyes are azo, anthraquinone and phthalocyanine (Ghodbane et al., 2010). There are a number of reasons why reactive dyes are the most often used in the dyeing process, e.g., good stability during washing, and relatively simple dyeing procedures (Kurbus et al., 2002; Muruganandham et al., 2004). These dyes are the most common in use today especially for dyeing of wool and cellulosic fibres such as cotton. Reactive dyes, which have good water solubility and are easily hydrolysed into insoluble forms, are extensively used in dyeing processes, and about $20-40 \%$ of these dyes remain in the effluent (Armagan et al., 2003). Thus, an effective and economical technique for removing reactive dyes from textile wastewater is needed.

In past decades, some techniques such as adsorption, membrane separation, coagulation, chemical oxidation, and electrochemical degradation have been investigated to treat

\footnotetext{
To whom all correspondence should be addressed.

용 +381 6310640 16; Fax: +381 18533 014;

e-mail: bojica@pmf.ni.ac.rs

Received 9 November 2012; accepted in revised form 25 June 2014.
}

dyeing wastewater. However, low removal efficiency or high cost in operation often limits their application (Wang et al., 2008). In recent years, advanced oxidation processes (AOPs) have been developed to treat the contaminants of natural water and industrial effluents. Earlier studies have shown that anthraquinone dyes can be removed by ozone (Kunc et al., 2002; Chen et al., 2009; Fanchiang et al., 2009), the combination of ozone and ultrasound, or electrochemical degradation in natural waters and effluents from the textile industry ( $\mathrm{He}$ et al., 2008; Kim et al., 2002; Rajkumar et al., 2007). $\mathrm{TiO}_{2}$ and $\mathrm{TiO}_{2}$-based catalysts were used for the photodegradation of anthraquinone dyes (Saquib et al., 2002; Lizama et al., 2002). Colonna et al. (1999) reported that homogenous advanced oxidation processes employing hydrogen peroxide with UV light lead to complete decolourisation and mineralisation of sulphonated azo and anthraquinone dyes. This process is based on the generation of hydroxyl radicals $(\bullet \mathrm{OH})$, and a strong oxidising agent $\left(\mathrm{E}^{0}=2.8 \mathrm{~V}\right)$, which degrade a broad range of organic pollutants quickly and non-selectively (Muruganandham et al., 2004; Aleboyeh et al., 2005; Daneshvar et al., 2005). Reaction of hydroxyl radicals generated in the presence of an organic substrate may occur via one of three general pathways: (i) hydrogen abstraction; (ii) electrophilic addition and (iii) electron transfer (Daneshvar et al., 2005). The method is inexpensive and non-toxic for treatment of water (Bilgi et al., 2005).

For practical application of the $\mathrm{UV} / \mathrm{H}_{2} \mathrm{O}_{2}$ process for treatment of dye-contaminated wastewater, it is important to determine the optimal experimental conditions. In this paper, the effects of initial $\mathrm{pH}$, initial dye concentration, initial concentration of $\mathrm{H}_{2} \mathrm{O}_{2}$ and the presence of inorganic salts on decolourisation of reactive dye C.I. Reactive Blue 19 (RB 19) by UV radiation in the presence of hydrogen peroxide were examined. 


\begin{tabular}{|l|l|c|c|c|c|}
\hline \multicolumn{7}{|c|}{ TABLE 1 } \\
\hline Molecular formula & Molecular mass $\left(\mathbf{g} \cdot \mathbf{m o l}^{-1}\right)$ & $\lambda_{\text {max }}(\mathbf{n m})$ & CAS number & C.I. number & $\mathrm{IC}_{50}\left(\mathbf{m g} \cdot \ell^{-1}\right)$ \\
\hline $\mathrm{C}_{22} \mathrm{H}_{16} \mathrm{~N}_{2} \mathrm{Na}_{2} \mathrm{O}_{11} \mathrm{~S}_{3}$ & 626.55 & 592 & $2580-78-1$ & 61200 & 55 \\
\hline
\end{tabular}

\section{EXPERIMENTAL}

\section{Reagents}

The anthraquinone reactive dye C.I. Reactive Blue 19 (RB 19) (molecular weight 626) was obtained from Sigma-Aldrich (USA) and used without any purification. Table 1 summarises the general characteristics of $\mathrm{RB} 19$. The $\mathrm{H}_{2} \mathrm{O}_{2}$ solution (30\%) and other used reagents $\left(\mathrm{NaCl}, \mathrm{Na}_{2} \mathrm{SO}_{4}, \mathrm{NaNO}_{3}\right.$, and $\mathrm{NaH} 2 \mathrm{PO} 4)$ were of analytical grade and purchased from Merck (Germany).

\section{Procedures}

A stock solution of RB 19 was made by dissolving $1.00 \mathrm{~g}$ dye in $1000 \mathrm{~m} \ell$ deionised water. Working solutions were freshly prepared, before irradiation, by diluting the stock to the desired concentration with deionised water. The $\mathrm{pH}$ of the solutions was adjusted by addition of $\mathrm{NaOH}$ or $\mathrm{HCl}\left(0.1 / 0.01 \mathrm{~mol} \cdot \ell^{-1}\right)$ measured with a $\mathrm{pH}$-meter (SensIon5, HACH, USA). All photochemical experiments were carried out in a batch photoreactor constructed in our laboratory facility and described in Mitrovic et al. (2012). During irradiation, the solution was magnetically stirred (Are, Velp Scientifica, Italy) at a constant rate and temperature was maintained at $25 \pm 0.5^{\circ} \mathrm{C}$. At required time intervals, $4 \mathrm{~m} \ell$ of samples were withdrawn and absorbance at $592 \mathrm{~nm}$ was measured using a UV/vis spectrophotometer Cintra 1010 (GBC, Australia) to determine the degree of decolourisation of the solution. The removal (\%) of RB 19 dye was calculated as:

$$
\text { Removal }(\%)=\left[1-\frac{c_{\mathrm{t}}}{c_{0}}\right] \times 100
$$

where:

$c_{0}$ and $c_{\mathrm{t}}$ are the concentration values of the dye solution before and after UV irradiation, respectively.

The total organic carbon (TOC) was also determined in order to evaluate the mineralisation rate, as an important indicator of treatment effectiveness. The TOC content was determined by a Shimadzu TOC-5000A analyser.

All experiments were carried out with 3 replicates. Average values \pm SD (error bars) are presented in all graphs. All statistical tests were performed by OriginPro 8 (OriginLab, USA) using a one-way ANOVA parametric method. The strength of the relationships, measured by the correlation coefficient $\left(R^{2}\right)$, as well as the significance of the relationships, expressed in probability levels ( $p$-values) was tested. Obtained correlation coefficients were statistically significant at a significance level of 95\% for all tests performed.

\section{RESULTS AND DISCUSSION}

Reactive dye C.I. Reactive Blue 19 (RB 19) was chosen as a representative of reactive dyes from the class of anthraquinones. It is characterised by high chemical stability and its

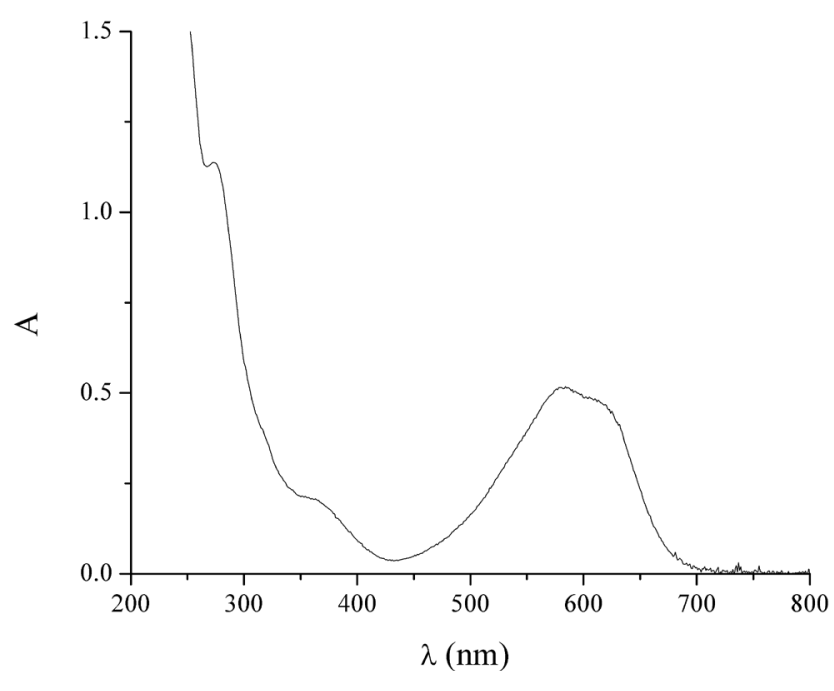

Figure 1

Absorption spectra of textile dye Reactive Blue 19

resistance to numerous physical and chemical influences present in the environment, where RB 19 can be found as a contaminant (Chang et al., 1986). The UV/vis absorption spectrum of RB 19 is presented in Fig. 1. Two absorbance peaks were observed during the scanning of the dye at $\mathrm{pH}$ 7.0. The visible peak at $592 \mathrm{~nm}$ is due to the blue colour of the dye chromophore. The peak observed in the UV region from 200 to $300 \mathrm{~nm}$ is due to the anthraquinone structure of the dye.

A basic photodecolourisation experiment was conducted for a time period of $20 \mathrm{~min}$ (initial dye concentration was 50.0 $\mathrm{mg} \cdot \ell^{-1}$, an initial $\mathrm{H}_{2} \mathrm{O}_{2}$ concentration of $25.0 \mathrm{mmol} \cdot \ell^{-1}$, and UV radiation intensity of $1950 \mu \mathrm{W} \cdot \mathrm{cm}^{-2}$ ). Decolourisation was monitored by measuring of absorbance at $592 \mathrm{~nm}$. The experimental results showed that the process is quite rapid and that most of the decolourisation was observed in the first $10 \mathrm{~min}$ of UV irradiation (85.7 $\pm 4.1 \%$ ), while in a period of $15 \mathrm{~min}$ complete decolourisation of samples was observed (Fig. 2). On the other hand, monitoring the absorbance peak at $230 \mathrm{~nm}$ during treatment suggested that degradation of the aromatic part of the dye molecule was a relatively slower process and incomplete in the investigated period of $20 \mathrm{~min} . R^{2}$ values were 0.983 and 0.990 for the curves at 230 and $592 \mathrm{~nm}$, respectively.

Figure 3 presents the difference between change of solution colour and TOC during the degradation of $50.0 \mathrm{mg} \cdot \ell^{-1}$ RB 19. The complete removal of colour was achieved within a short period of time $(15 \mathrm{~min})$. In the same time, TOC removal was $15.8 \pm 0.8 \%$, while almost complete removal of $93.5 \pm 4.7 \%$ was achieved after $240 \mathrm{~min}$. It is well known that the removal of colour is due to cleavage of chromophore bonds in the dye molecule, which is a faster process than the complete oxidative degradation of molecules of dye to low molecular mass compounds (Mitrovic et al., 2012; Guimaraes et al., 2012).

A combination of UV light and $\mathrm{H}_{2} \mathrm{O}_{2}$ is required for production of $\bullet \mathrm{OH}$ radicals by photolysis of the $\mathrm{H}_{2} \mathrm{O}_{2}$. The 


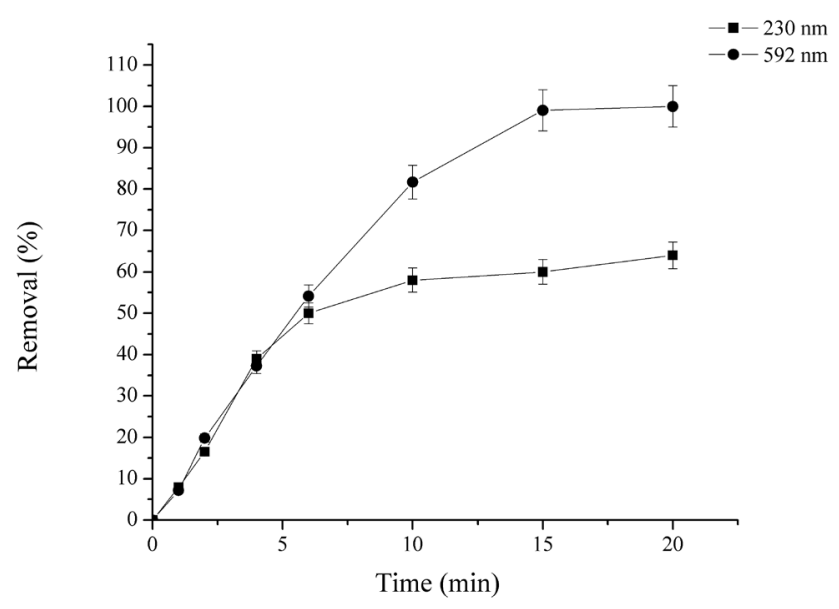

\begin{tabular}{|l|c|c|}
\hline \multicolumn{3}{|c|}{ TABLE 2 } \\
$\begin{array}{r}\text { Pseudo-first order rate constants of RB } \\
\text { 19 decolourisation in function of } \mathrm{pH} . \\
{[\mathrm{RB} 19]_{0}=50 \mathrm{mg} \cdot \ell^{-1},} \\
\left.\text { 25 } \mathrm{mmol}_{2} \mathbf{O}_{2}\right]_{0}=\end{array}$ \\
\hline $\mathrm{pH}$ & $k_{\text {app }}\left(\mathrm{min}^{-1}\right)$ & $R^{2}$ \\
\hline 2 & 0.0777 & 0.9804 \\
\hline 3 & 0.0797 & 0.9879 \\
\hline 4 & 0.0816 & 0.9869 \\
\hline 5 & 0.0977 & 0.9832 \\
\hline 7 & 0.1113 & 0.9898 \\
\hline 9 & 0.1305 & 0.9904 \\
\hline 10 & 0.1684 & 0.9949 \\
\hline 11 & 0.1816 & 0.9967 \\
\hline
\end{tabular}

Figure 2

Removal of dye $\mathrm{RB} 19$ by UV/ $\mathrm{H}_{2} \mathrm{O}_{2}$ process. $[R B 19]_{0}=50 \mathrm{mg} \cdot \ell^{-1}$, $\left[\mathrm{H}_{2} \mathrm{O}_{2}\right]_{0}=25 \mathrm{mmol} \cdot \ell^{-1}$, initial $\mathrm{pH} 7, \mathrm{UV}$ radiation intensity was $1950 \mu \mathrm{W} \cdot \mathrm{cm}^{-2}$, temperature was $25.0 \pm 0.5^{\circ} \mathrm{C}$.

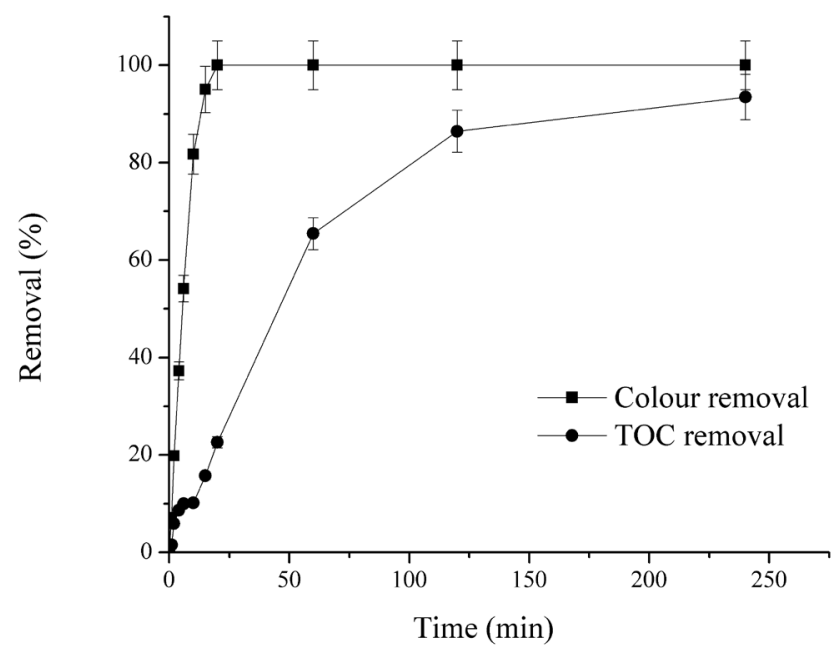

Figure 3

Change of colour and TOC during UV/ $\mathrm{H}_{2} \mathrm{O}_{2}$ treatment of RB 19

hydroxyl radical is a non-selective and very powerful oxidising agent and can initiate the decolourisation reactions by reacting with the dye molecules (Zollinger, 2003; Muruganandham et al., 2004; He et al., 2008; Aleboyeh et al., 2005; Daneshvar et al., 2005; Aleboyeh et al., 2003; Daneshvar et al., 2003).

$$
\mathrm{H}_{2} \mathrm{O}_{2}+\mathrm{hv} \stackrel{\mathrm{k}_{1}}{\longrightarrow} 2 \mathrm{HO}^{\bullet}
$$

$$
\mathrm{HO}^{\bullet}+\text { dye } \stackrel{k_{2}}{\longrightarrow} \text { Intermediate products (I) }
$$

Intermediate products $(\mathrm{I})+\mathrm{HO}^{\bullet} \stackrel{k_{3}}{\longrightarrow}$ Products $\left(\mathrm{P}_{\mathrm{i}}\right)$

According to the results of other studies (El-Dein et al., 2003; Dong et al., 2007; Mitrovic et al., 2012), the photodecolourisation is a pseudo-first order reaction with respect to the dye concentration. The kinetic pathway of decolourisation could be expressed as follows:

$$
-\frac{\mathrm{d} c_{\mathrm{t}}}{\mathrm{d} t}=\mathrm{k}_{\mathrm{app}} t
$$

where:

$k_{a p p}\left(\mathrm{~min}^{-1}\right)$ is the apparent pseudo-first rate constant,

$c_{\mathrm{t}}$ is the concentration of dye after irradiation time $t$.

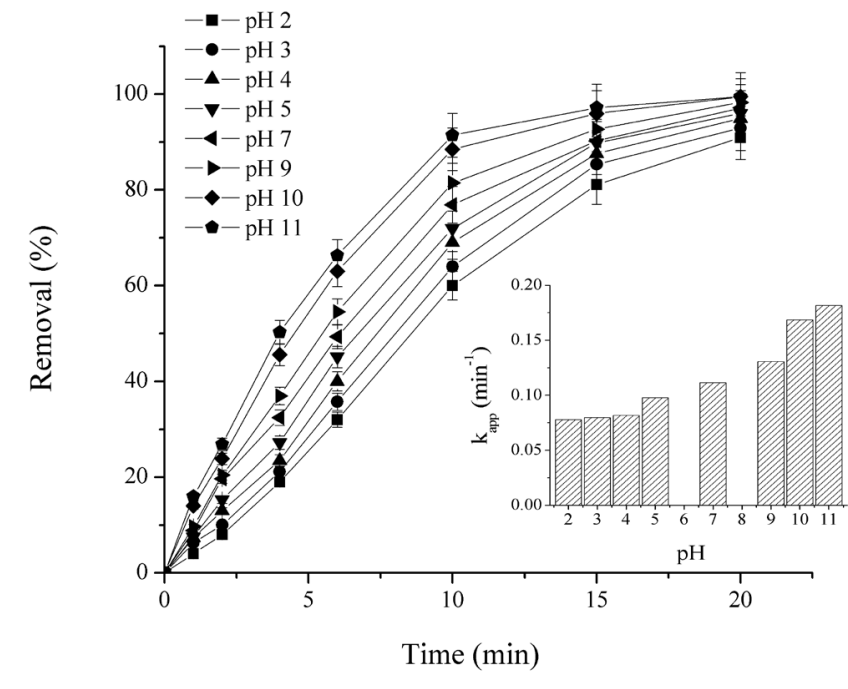

Figure 4

Effect of initial $p H$ on removal of $R B$ 19. $[R B 19]_{0}=50 \mathrm{mg} \cdot \ell^{-1},\left[\mathrm{H}_{2} \mathrm{O}_{2}\right]_{0}=$ $25 \mathrm{mmol} \cdot \ell^{-1}, \mathrm{UV}$ radiation intensity was $1950 \mu \mathrm{W} \cdot \mathrm{cm}^{-2}$, temperature was $25.0 \pm 0.5^{\circ} \mathrm{C}$. Inset shows the relation between pseudo-first order rate constants and initial $\mathrm{pH}$.

This equation, after integration with the initial condition $\left(\mathrm{c}_{0}\right.$ for $t=0)$, leads to:

$$
\ln \left(c_{\mathrm{t}} / c_{0}\right)=-\mathrm{k}_{\mathrm{app}} t
$$

where:

$k_{a p p}\left(\mathrm{~min}^{-1}\right)$ is the apparent pseudo-first rate constant,

$c_{\mathrm{t}}$ is the concentration of dye after irradiation time $t$,

$c_{0}$ is the dye concentration at $t=0$.

The apparent reaction rate constants $\left(k_{a p p}\right)$ for decolourisation of RB 19 were calculated from semi-logarithmic graphs of $\ln \left(c_{t} / c_{0}\right)$ versus time, using the linear regression method. The values were also calculated for $R^{2}$ ( 0.989 for colour removal and 0.987 for TOC removal).

\section{Effect of initial pH}

The effect of $\mathrm{pH}$ on the rate of decolourisation of textile dye $\mathrm{RB} 19$ with $\mathrm{UV} / \mathrm{H}_{2} \mathrm{O}_{2}$ process was studied at $\mathrm{pH}$ values of 2 , $3,4,5,7,9,10$ and 11 . For an initial dye concentration of 50.0 $\mathrm{mg} \cdot \ell^{-1}$ and initial $\mathrm{H}_{2} \mathrm{O}_{2}$ concentration of $25 \mathrm{mmol} \cdot \ell^{-1}$, the initial decolourisation rate at different $\mathrm{pH}$ values is shown in Fig. 4. 


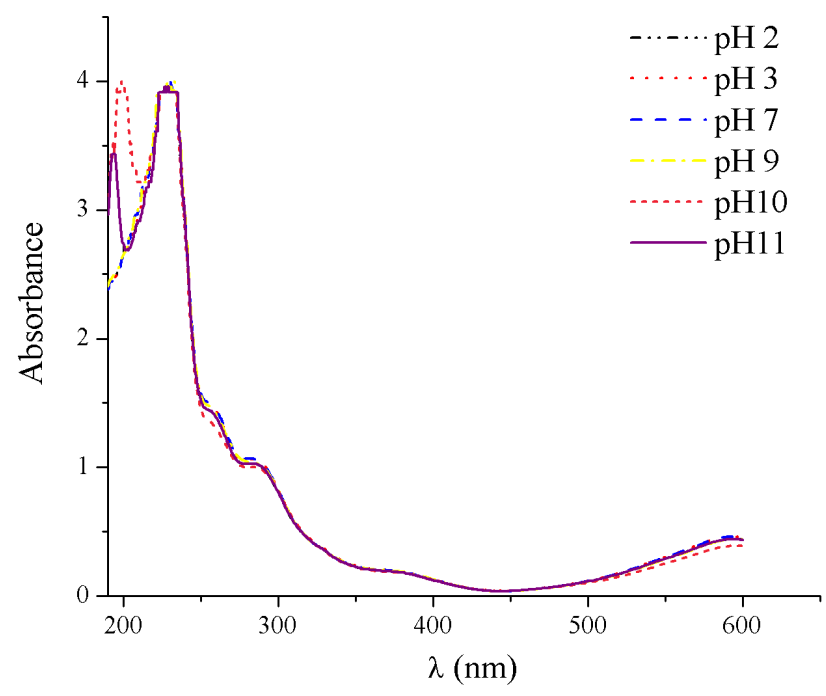

Figure 5

Absorption spectra of textile dye Reactive Blue 19 at different $\mathrm{pH}$ values. $[R B 19]_{0}=50 \mathrm{mg} \cdot \ell^{-1}$.

Decolourisation efficiency increased with increasing $\mathrm{pH}$ from 2 to 11 . The values of the apparent pseudo-first rate constant, $k_{a p p}$, and correlation coefficient $\left(R^{2}\right)$ are presented in Table 2. In all experiments, the values of $R^{2}$ were higher than 0.98 .

For an acidic $\mathrm{pH}$, with acidification of the solution by $\mathrm{HCl}$ (dye solution with initial $\mathrm{pH}$ 2, 3, 4 and 5), the amounts of conjugated base $\mathrm{Cl}^{-}$ions increase. The anion $\mathrm{Cl}^{-}$can react with - $\mathrm{OH}$ leading to the formation of inorganic radical ions $\mathrm{ClOH}$ • (Reaction (7)) (Aleboyeh et al., 2005; Jaysona et al., 1973). These inorganic radical anions show a lower reactivity than $\bullet \mathrm{OH}$, so that they do not play a role in the decolourisation of RB 19.

$$
\mathrm{Cl}^{-}+\mathrm{HO}^{\bullet} \longrightarrow \mathrm{ClHO}^{{ }^{-}}, \mathrm{k}=4.3 \times 10^{9} \mathrm{M}^{-1} \mathrm{~s}^{-1}
$$

With further increases in $\mathrm{pH}$, to $\mathrm{pH} 11$, there is a continuous increase in the efficiency of the dye decolourisation process (Fig. 4). It is known that increasing the $\mathrm{pH}$ of the solution increases the concentration of $\mathrm{HO}_{2}{ }^{-}$, the peroxide conjugate base (Reaction (8)) (Aleboyeh et al., 2005; Xu et al., 2009). $\mathrm{HO}_{2}{ }^{-}$absorbs the radiation at $254 \mathrm{~nm}$ more intensely than the peroxide, which should lead to an increase in the concentration of $\bullet \mathrm{OH}$ radicals (Reaction (9)) (Aleboyeh et al., 2005; Lergini et al., 1993; Beltran et al., 1997).

$$
\begin{aligned}
& \mathrm{H}_{2} \mathrm{O}_{2} \longrightarrow \mathrm{HO}_{2}{ }^{-}+\mathrm{H}^{+}, \mathrm{pK}_{\mathrm{a}}=11.6 \\
& \mathrm{HO}_{2}{ }^{-}+\mathrm{H}^{+}+h v \longrightarrow 2 \mathrm{HO}
\end{aligned}
$$

But $\mathrm{HO}_{2}{ }^{-}$, the conjugate anion of $\mathrm{H}_{2} \mathrm{O}_{2}$, reacts with a nondissociated molecule of $\mathrm{H}_{2} \mathrm{O}_{2}$ according to Reaction (10), which leads to oxygen $\left(\mathrm{O}_{2}\right)$ and water, instead of producing hydroxyl radicals under UV radiation (Reaction (9)). Therefore, the instantaneous concentration of $\bullet \mathrm{OH}$ is lower than expected.

$$
\mathrm{HO}_{2}{ }^{-}+\mathrm{H}_{2} \mathrm{O}_{2} \longrightarrow \mathrm{H}_{2} \mathrm{O}+\mathrm{O}_{2}+\mathrm{OH}^{-}
$$

Additionally, at high $\mathrm{pH}$ values deprotonation of the RB 19 molecule probably took place, which was confirmed in a study of another anthraquinone dye with a similar structure (Epolito et al., 2005). These structural changes could make the RB 19

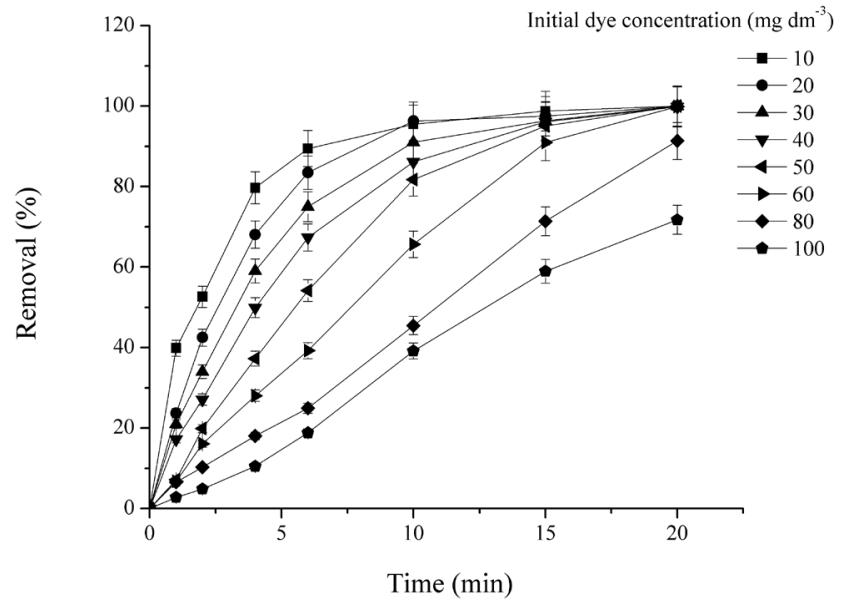

Figure 6

Effect of initial dye concentration on removal of RB 19 $\left[\mathrm{H}_{2} \mathrm{O}_{2}\right]_{0}=25 \mathrm{mmol} \cdot \ell^{-1}$, initial $\mathrm{pH}$ was $7, \mathrm{UV}$ radiation intensity was $1950 \mu \mathrm{W} \cdot \mathrm{cm}^{-2}$, temperature was $25.0 \pm 0.5 \mathrm{VC}$

dye molecule especially vulnerable to $\bullet \mathrm{OH}$ radical attack, leading to an increase in decolourisation rate.

\section{Effect of initial dye concentration}

The effect of initial dye concentration on decolourisation by the $\mathrm{UV} / \mathrm{H}_{2} \mathrm{O}_{2}$ process is shown in Fig. 6. It was found that by increasing the initial dye concentration from 10 to $100 \mathrm{mmol} \cdot \ell^{-1}$ decolourisation decreased $\left(R^{2}=0.986-0.999\right)$. After $10 \mathrm{~min}$ of treatment, samples with lower initial concentrations were completely decolourised. The decrease in decolourisation efficiency with increase in dye initial concentration can be explained by the internal filter effect (Ghodbane et al., 2010; Elmorsi et al., 2010). An increase in dye concentration induces a rise in internal optical density and the solution becomes more and more impermeable to UV irradiation. In this way, $\mathrm{H}_{2} \mathrm{O}_{2}$ can only be irradiated by a small portion of UV light to form fewer free radicals and colour removal decreases (Elmorsi et al., 2010; Ghodbane et al., 2010; Muruganandham et al., 2004; Aleboyeh et al., 2005; Behnajady et al., 2004; Galindo et al., 1998).

\section{Effect of initial $\mathrm{H}_{2} \mathrm{O}_{2}$ concentration}

Hydrogen peroxide concentration is an important parameter for the degradation of dye by the $\mathrm{UV} / \mathrm{H}_{2} \mathrm{O}_{2}$ process. The effect of initial peroxide concentration on decolourisation of $\mathrm{RB} 19$ dye has been studied at an initial $\mathrm{H}_{2} \mathrm{O}_{2}$ concentration ranging from 10 to $100 \mathrm{mmol} \cdot \ell^{-1}$. Results show that increasing $\mathrm{H}_{2} \mathrm{O}_{2}$ concentration increased dye removal, until the concentration of peroxide reaches approximately $30 \mathrm{mmol} \cdot \ell^{-1}$ (Fig. 7). In this range, the apparent pseudo-first rate constant increases from $0.083 \mathrm{~min}^{-1}$ to $0.120 \mathrm{~min}^{-1}$. At $\mathrm{H}_{2} \mathrm{O}_{2}$ concentrations above $30 \mathrm{mmol} \cdot \ell^{-1}$ the process rate decreases. At low concentrations of $\mathrm{H}_{2} \mathrm{O}_{2}, \cdot \mathrm{OH}$ radical concentration is proportionally low, which results in a low decolourisation rate. In all experiments, the values of $R^{2}$ were higher than 0.98 .

By increasing the peroxide concentration more and more hydroxyl radicals are generated. The $\bullet \mathrm{OH}$ free radicals produced upon photolysis of $\mathrm{H}_{2} \mathrm{O}_{2}$ can react with dye molecules, but also with an excess of $\mathrm{H}_{2} \mathrm{O}_{2}$. Excess of hydrogen peroxide and high $\bullet \mathrm{OH}$ radical concentration results in competitive 


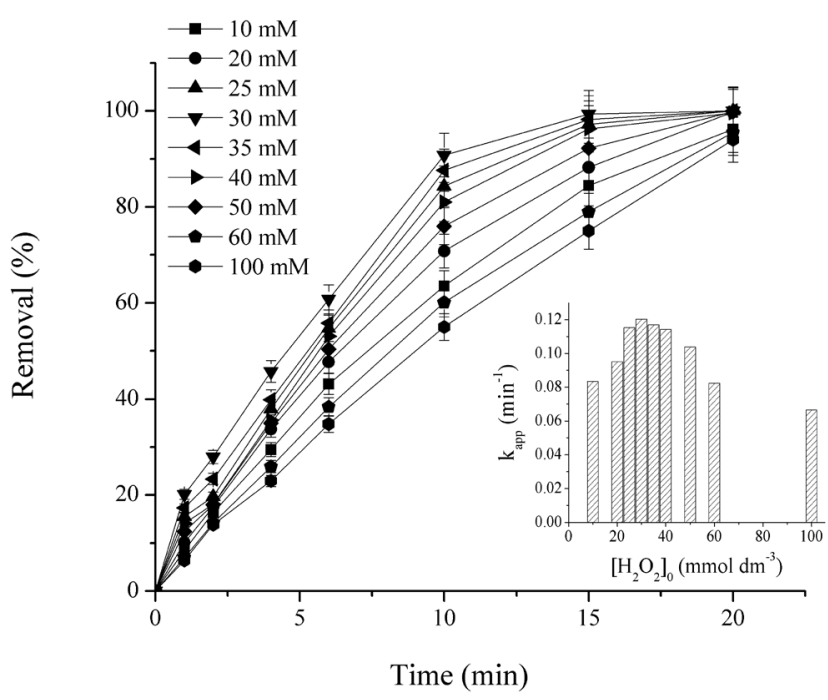

Figure 7

Effect of initial concentration of peroxide on removal of RB 19. [RB19] $=50 \mathrm{mg} \cdot \ell^{-1}$, initial $\mathrm{pH}=7, \mathrm{UV}$ radiation intensity was $1950 \mu \mathrm{W} \cdot \mathrm{cm}^{-2}$, temperature was $25.0 \pm 0.5^{\circ} \mathrm{C}$. Inset shows the relation between pseudofirst order rate constants and initial concentration of peroxide.

reactions, producing an inhibitory effect on decolourisation (Zollinger et al., 2003; Muruganandham et al., 2004; Aleboyeh et al., 2005; Rezaee et al., 2008).

Other authors have produced similar results in their investigation of this dye. Rezaee et al. (2008) and Guimaraes et al. (2012) also observed high decolourisation of RB 19 solution by the $\mathrm{UV} / \mathrm{H}_{2} \mathrm{O}_{2}$ process; using $\mathrm{H}_{2} \mathrm{O}_{2}$ and a low-pressure mercury UV-C lamp, the solution was completely decolourised in less than 30 min.

With a further increase in initial concentration of peroxide from 30 to $100 \mathrm{mmol} \cdot \ell^{-1}$, the rate of decolourisation is reduced and $\mathrm{k}_{\text {app }}$ values decreased, almost by half, from $0.120 \mathrm{~min}^{-1}$ to $0.066 \mathrm{~min}^{-1}$. When the initial peroxide concentration is very high, generated $\bullet \mathrm{OH}$ are mostly reacting with the excess of peroxide and produce $\mathrm{HO}_{2} \bullet$ radicals, according to Reaction (11) (Aleboyeh et al., 2005; Daneshvar et al., 2005). It is clear that $\mathrm{HO}_{2} \bullet$ radicals are less reactive than $\bullet \mathrm{OH}$ radicals and the decolourisation rate decreases (Daneshvar et al., 2005).

$$
\mathrm{H}_{2} \mathrm{O}_{2}+\mathrm{HO}^{\bullet} \longrightarrow \mathrm{H}_{2} \mathrm{O}+\mathrm{HO}_{2}{ }^{\bullet}, \mathrm{k}=2.7 \times 10^{7} M^{-1} s^{-1}
$$

Generated $\bullet \mathrm{OH}$ radicals can also react with $\mathrm{HO}_{2} \bullet$ and produce water and dioxigen (Reaction (12)) or dimerize to $\mathrm{H}_{2} \mathrm{O}_{2}$ (Reaction (13)) (Aleboyeh et al., 2005; Daneshvar et al., 2005):

$$
\begin{aligned}
& \mathrm{HO}^{\bullet}+\mathrm{HO}_{2} \cdot \longrightarrow \mathrm{H}_{2} \mathrm{O}+\mathrm{O}_{2}, k=6.6 \times 10^{9} M^{-1} s^{-1} \\
& \mathrm{HO}^{\bullet}+\mathrm{HO}^{\bullet} \longrightarrow \mathrm{H}_{2} \mathrm{O}_{2}, \mathrm{k}=5.5 \times 10^{9} M^{-1} s^{-1}
\end{aligned}
$$

Therefore, the optimum value of $\mathrm{H}_{2} \mathrm{O}_{2}$ concentration for the maximum decolourisation rate for $\mathrm{RB} 19$ was approximately $30 \mathrm{mmol} \cdot \ell^{-1}$.

\section{Effect of UV radiation intensity}

With increasing UV radiation intensity, the efficiency of dye decolourisation increases considerably. Based on the results obtained (Fig. 8), it can be concluded that the decolourisation

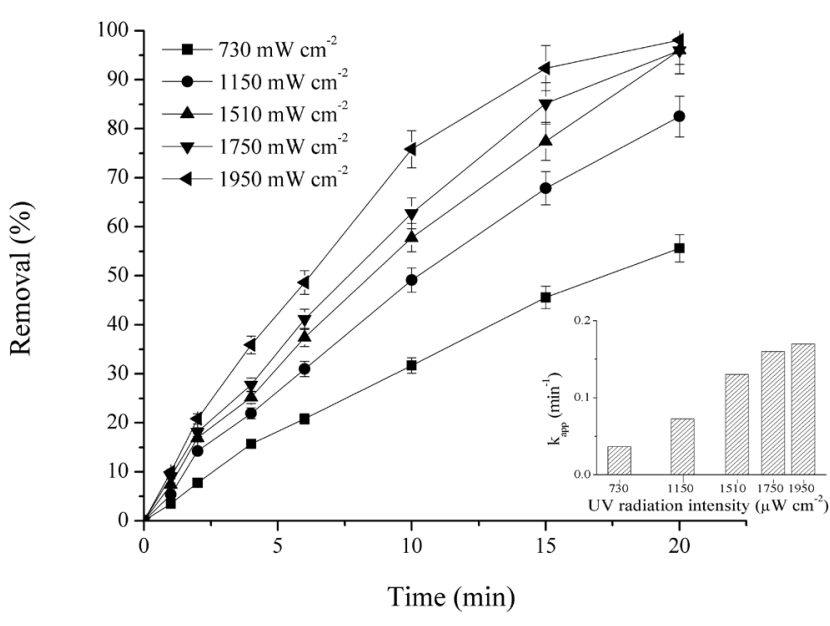

Figure 8

Effect of radiation intensity on removal of $R B$ 19. [RB19] $=50 \mathrm{mg} \cdot \ell^{-1}$, $\left[\mathrm{H}_{2} \mathrm{O}_{2}\right]_{0}=25 \mathrm{mmol} \cdot \ell^{-1}$, initial $=p H 7$, temperature was $25.0 \pm 0.5^{\circ} \mathrm{C}$. Inset shows the relation between pseudo-first order rate constants and radiation intensity.

rate constant of the dye increases with the increase in radiation intensity from $730 \mu \mathrm{W} \cdot \mathrm{cm}^{-2}$ to $1950 \mu \mathrm{W} \cdot \mathrm{cm}^{-2}$. The smallest increase in process efficiency took place from $1750 \mu \mathrm{W} \cdot \mathrm{cm}^{-2}$ to $1950 \mu \mathrm{W} \cdot \mathrm{cm}^{-2}$; from this it follows that the back lamps in the photoreactor contribute least to dye decolourisation. The results also show that the UV intensity tested in the study lies in the linear range and that all photons produced are effectively used (Fig. 8). $R^{2}$ values were from 0.995 to 0.998 .

The results of this investigation are consistent with previous studies which generally observed an increase in decolourisation rate with increasing UV intensity (Mills et al., 1993; Lea et al., 1998). This is a consequence of a higher quantity of generated - $\mathrm{OH}$ radicals, which make the oxidative degradation of anthraquinone dye more efficient.

\section{Effect of inorganic ions}

It is well known in the textile industry that in order to accelerate or increase the fixation of dyes onto the fibres, it is necessary to use a high electrolyte concentration in the dye bath to decrease the negatively-charged barrier between the cellulose and anionic dyes (Carneiro et al., 2004; Kampyli et al., 2004). We examined the effects of several types of inorganic ions $\left(\mathrm{Cl}^{-}\right.$, $\mathrm{SO}_{4}{ }^{2-}, \mathrm{NO}_{3}^{-}, \mathrm{H}_{2} \mathrm{PO}_{4}^{-}$) common in synthetic dye-containing effluent on the photodecolourisation of dyes under UV irradiation. Experiments were done at three different concentrations of inorganic ions: 10, 100 and $1000 \mathrm{mmol} \ell^{-1}$.

The 20-min decolourisation and the reduction in decolourisation efficiency when adding inorganic anions to RB 19 solutions are shown in Table 3. The degree of inhibition of the process did not increase linearly with increasing inorganic ion concentrations. Furthermore, the overall inhibition is not too extensive despite the fact that high concentrations of inorganic anions are present in solution. This confirms that the $\mathrm{UV} / \mathrm{H}_{2} \mathrm{O}_{2}$ process can be successfully applied for decolourisation of real textile wastewater which commonly contains high concentrations of inorganic anions.

It can be seen that the 20 -min decolourisation efficiency was adversely affected and decreased as the inorganic ion concentrations increased from 10 to $1000 \mathrm{mmol} \cdot \ell^{-1}$ (Fig. 9). 


\begin{tabular}{|c|c|c|c|c|}
\hline \multicolumn{5}{|c|}{$\begin{array}{c}\text { TABLE } 3 \\
20 \text { min decolourisation vs. type of anion and reduction in decolourisation efficiency }\end{array}$} \\
\hline Anion $/ C_{\text {salt }}$ & & $10 \mathrm{mmol} \cdot \ell^{-1}$ & $100 \mathrm{mmol} \cdot \ell^{-1}$ & $1000 \mathrm{mmol} \cdot \ell^{-1}$ \\
\hline No salt & Total decolourisation (\%) & 100 & 100 & 100 \\
\hline $\mathrm{NO}_{3}^{-}$ & $\begin{array}{l}\text { Total decolourisation (\%) } \\
\text { Reduction in decolourisation efficiency (\%) }\end{array}$ & $\begin{array}{c}81.88 \\
-18.12 \\
\end{array}$ & $\begin{array}{c}73.62 \\
-26.38 \\
\end{array}$ & $\begin{array}{c}73.62 \\
-26.38 \\
\end{array}$ \\
\hline $\mathrm{Cl}^{-}$ & $\begin{array}{l}\text { Total decolourisation (\%) } \\
\text { Reduction in decolourisation efficiency (\%) }\end{array}$ & $\begin{array}{r}91.27 \\
-8.73\end{array}$ & $\begin{array}{c}86.52 \\
-13.48 \\
\end{array}$ & $\begin{array}{c}79.07 \\
-20.92\end{array}$ \\
\hline $\mathrm{SO}_{4}^{2-}$ & $\begin{array}{l}\text { Total decolourisation (\%) } \\
\text { Reduction in decolourisation efficiency (\%) }\end{array}$ & $\begin{array}{c}89.45 \\
-10.55\end{array}$ & $\begin{array}{c}81.01 \\
-18.85\end{array}$ & $\begin{array}{c}72.00 \\
-28.00\end{array}$ \\
\hline $\mathrm{H}_{2} \mathrm{PO}_{4}^{-}$ & $\begin{array}{l}\text { Total decolourisation (\%) } \\
\text { Reduction in decolourisation efficiency (\%) }\end{array}$ & $\begin{array}{c}84.15 \\
-15.84 \\
\end{array}$ & $\begin{array}{c}75.89 \\
-24.10 \\
\end{array}$ & $\begin{array}{c}53.13 \\
-46.87 \\
\end{array}$ \\
\hline
\end{tabular}

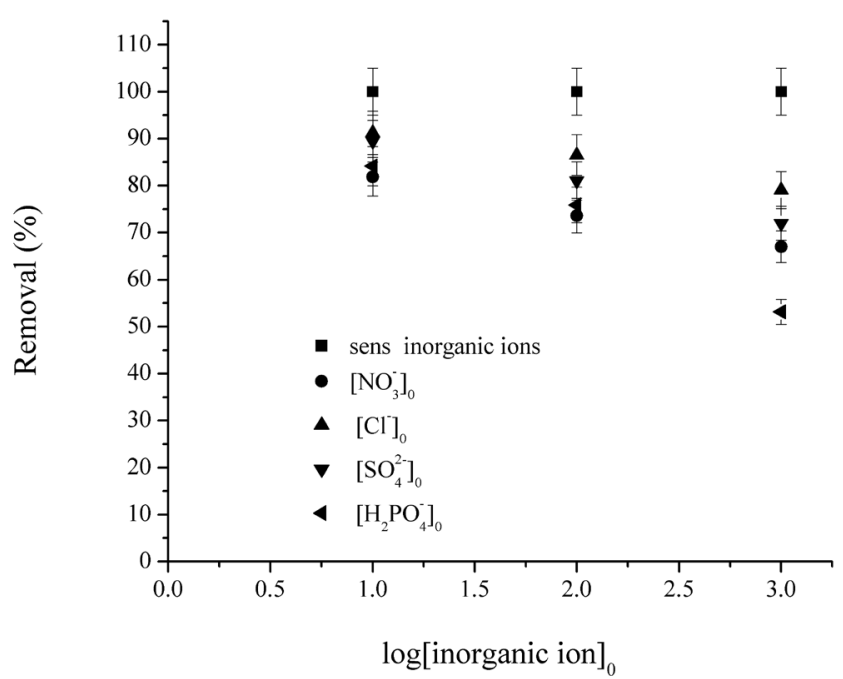

Figure 9

Effect of initial inorganic ion concentrations on removal of $R B 19$ $[R B 19]_{0}=50 \mathrm{mg} \cdot \ell^{-1},\left[\mathrm{H}_{2} \mathrm{O}_{2}\right]_{0}=25 \mathrm{mmol} \cdot \ell^{-1}, \mathrm{UV}$ radiation intensity was $1950 \mu \mathrm{W} \cdot \mathrm{cm}^{-2}$, temperature was $25.0 \pm 0.5^{\circ} \mathrm{C}$.

At $10 \mathrm{mmol} \cdot \ell^{-1}$ and $100 \mathrm{mmol} \cdot \ell^{-1}$ the order of inhibition measured was the following: $\mathrm{NO}_{3}^{-}>\mathrm{H}_{2} \mathrm{PO}_{4}^{-}>\mathrm{SO}_{4}{ }^{2-}>\mathrm{Cl}^{-}$, while at the higher concentration of $1000 \mathrm{mmol}-\ell^{-1}$, the order of inhibition measured was: $\mathrm{H}_{2} \mathrm{PO}_{4}^{-}>\mathrm{NO}_{3}^{-}>\mathrm{SO}_{4}^{2-}>\mathrm{Cl}^{-}\left(R^{2}=0.964-0.999\right)$.

The inhibiting effect of inorganic ions can be explained by the fact that these anions act as $\bullet \mathrm{OH}$ radical scavengers, which protect a dye molecule from oxidation (Galindo et al., 2001; Liao et al., 2001). These anions are able to react with hydroxyl radicals leading to inorganic radical ions which show a much lower reactivity than $\bullet \mathrm{OH}$, so that they do not play a role in dye decolourisation. There is also competition between the dye and anions with respect to $\bullet \mathrm{OH}$.

$$
\begin{aligned}
& \mathrm{Cl}^{-}+\mathrm{HO}^{\bullet} \longrightarrow \mathrm{ClHO}^{\bullet-}, \mathrm{k}=4.3 \times 10^{9} \mathrm{M}^{-1} \mathrm{~s}^{-1} \\
& \mathrm{NO}_{3}{ }^{-}+\mathrm{HO} \cdot \longrightarrow \mathrm{NO}_{3}{ }^{\bullet}+\mathrm{H}_{2} \mathrm{O}, \mathrm{k}=1.3 \times 10^{8} M^{-1} \mathrm{~s}^{-1} \\
& \mathrm{HSO}_{4}{ }^{-}+\mathrm{HO} \longrightarrow \mathrm{SO}_{4}{ }^{--}+\mathrm{H}_{2} \mathrm{O}, \mathrm{k}=4.7 \times 10^{5} M^{-1} \mathrm{~s}^{-1} \\
& \mathrm{H}_{2} \mathrm{PO}_{4}{ }^{-}+\mathrm{HO}^{\bullet} \longrightarrow \mathrm{HPO}_{4}{ }^{-}+\mathrm{H}_{2} \mathrm{O}, \mathrm{k}=2 \times 10^{4} M^{-1} \mathrm{~s}^{-1}
\end{aligned}
$$

Jaysona et al. (1973) reported that the rate constant for the interaction between $\bullet \mathrm{OH}$ radicals and $\mathrm{Cl}^{-}$anions is $k=4.3 \times 10^{9}$ $\mathrm{M}^{-1} \mathrm{~s}^{-1}$ (Reaction (7)). Kastruma et al. (1991) investigated the reactivity of $\mathrm{NO}_{3} \cdot$ radicals and got the value for rate constant $1.3 \times 10^{8} \mathrm{M}^{-1} \mathrm{~s}^{-1}$ for reaction of $\bullet \mathrm{OH}$ radical with $\mathrm{NO}_{3}{ }^{-}$(Reaction (14)). Results of Jiang et al. (1992) and Maruthamuthu et al. (1978), studies showed that $\mathrm{HSO}_{4}^{2-}$ and $\mathrm{H}_{2} \mathrm{PO}_{4}{ }^{-}$anions react with $\bullet \mathrm{OH}$ radical with lower rate $\left(\mathrm{k}=4.7 \times 10^{5} \mathrm{M}^{-1} \mathrm{~s}^{-1}\right.$ and $\mathrm{k}=2 \times 10^{4} \mathrm{M}^{-1} \mathrm{~s}^{-1}$, respectively) than $\mathrm{NO}_{3}{ }^{-}$(Reactions (15) and (16)). Therefore, the obtained scavenging effect of used anions in this study is not in agreement with the values of the rate constants given in the mentioned literature.

\section{CONCLUSION}

The results of the present work showed that the $\mathrm{UV} / \mathrm{H}_{2} \mathrm{O}_{2}$ process can be applied as an effective technology for the removal of Reactive Blue 19 from natural and waste waters. Complete decolourisation was achieved after less than $15 \mathrm{~min}$. It was found that with increasing solution $\mathrm{pH}$ decolourisation rate increases. The decolourisation of dye decreases by increasing the initial dye concentration from 10 to $100 \mathrm{mmol} \cdot \ell^{-1}$. As the initial concentration of $\mathrm{H}_{2} \mathrm{O}_{2}$ increased from 10 to $30 \mathrm{mmol} \cdot \ell^{-1}$, the decolourisation rate constant increased from $0.083 \mathrm{~min}^{-1}$ to $0.120 \mathrm{~min}^{-1}$, while at concentrations above this the process rate decreased. Increasing UV radiation intensity linearly increases the efficiency of dye photodecolourisation. The addition of $\mathrm{Cl}^{-}$, $\mathrm{SO}_{4}{ }^{2-}, \mathrm{NO}_{3}{ }^{-}$or $\mathrm{H}_{2} \mathrm{PO}_{4}{ }^{-}$to the dye solutions examined generally had an adverse effect on the decolourisation rates, but to a varying degree depending on the ion used. The results showed that the degree of inhibition of the process did not increase linearly with an increase in inorganic ion concentration.

\section{ACKNOWLEDGEMENT}

The authors would like to acknowledge the financial support of the Serbian Ministry of Education Science and Technological Development (Grant No TR34008).

\section{REFERENCES}

ALEBOYEH A, ALEBOYEH H and MOUSSA Y (2003) "Critical" effect of hydrogen peroxide in photochemical oxidative decolourisation of dyes: Acid Orange 8, Acid Blue 74 and Methyl Orange. Dyes Pigm. 57 67-75.

ALEBOYEH A, MOUSSA Y and ALEBOYEH H (2005) The effect of operational parameters on $\mathrm{UV} / \mathrm{H} 2 \mathrm{O} 2$ decolourisation of Acid Blue 74. Dyes Pigm. 66 129-134.

ARMAGAN B, OZDEMIR O, TURAN M and ÇELIK MS (2003) Adsorption of negatively charged azo dyes onto surfactant-modified sepiolite. J. Environ. Eng. 129 709-715.

BEHNAJADY MA, MODIRSHAHLA N and SHOKRI M (2004) Photodestruction of Acid Orange 7 (AO7) in aqueous solutions by 
$\mathrm{UV} / \mathrm{H} 2 \mathrm{O} 2$ : influence of operational parameters. Chemosphere 55 129-134.

BELTRAN FJ, GONZALEZ M and GONZALEZ JF (1997) Industrial wastewater advanced oxidation. Part 1 . UV radiation in the presence and absence of hydrogen peroxide or UV radiation. Water Res. 31 (10) 2405-2414.

BILGI S and DEMIR C (2005) Identification of photooxidation degradation products of C.I. Reactive Orange 16 dye by gas chromatography mass spectrometry. Dyes Pigm. 66 69-76.

CARNEIRO PA, OSUGI ME, SENE JJ ANDERSON MA and ZANONI MVB (2004) Evaluation of color removal and degradation of a reactive textila azo dye on nanoporous $\mathrm{TiO} 2$ thin film electrodes. Electrochim. Acta 49 3807-3820.

CHANG IY and MILLER IK (1986) Photostability of antraquinone and azo dyes in n-ethylacetamide (Nylon Model). J. Soc. Dyers Colour. 102 (2) 46-53.

CHEN TY, KAO CM, HONG A, LIN CE and LIANG SH (2009) Application of ozone on the decolourisation of reactive dyes Orange-13 and Blue-19. Desalination 249 1238-1242.

COLONNA GM, CARONNA T and MARCANDALLI B (1999) Oxidative degradation of dyes by ultraviolet radiation in presence of hydrogen peroxide. Dyes Pigm. 41 211-220.

DANESHVAR N, RABBANI M, MODIRSHAHLA N and BEHNAJADY MA (2004) Critical effect of hydrogen peroxide concentration in photochemical oxidative degradation of C.I. Acid Red 27 (AR27). Chemosphere 56 895-900.

DANESHVAR N, RABBANI M, MODIRSHAHLA N and BEHNAJADY MA (2005) Photooxidative degradation of Acid Red 27 in tubular continuous-flow photoreactor: influence of operational parameters and mineralization products. J. Hazardous Mater. B $118155-160$.

DONG X, DING W, ZHANG X and LIANG X (2007) Mechanism and kinetics model of degradation of synthetic dyes by UV-vis/H2O2/ Ferrioxalate complexes. Dyes Pigm. 74 470-476.

EL-DEIN AM, LIBRA JA and WIESMANN U (2003) Mechanism and kinetic model for the decolourisation of the azo dye Reactive Black 5 by hydrogen peroxide and UV radiation. Chemosphere 52 1069-1077.

ELMORSI TM, RIYAD YM, MOHAMED ZH and ABD EL BARY HMH (2010) Decolourisation of Mordant red 73 azo dye in water using $\mathrm{H}_{2} \mathrm{O}_{2} / \mathrm{UV}$ and photo-Fenton treatment. J. Hazardous Mater. $174352-358$.

EPOLITO WJ, LEE YH, BOTTOMLEY LA and PAVLOSTATHIS SG (2005) Characterization of the texile anthraquinone dye Reactive Blue 4. Dyes Pigm. 67 35-46.

FANCHIANG JM and TSENG DH (2009) Degradation of antraquinone dye C.I. Reactive Blue 19 in aqueous solution by ozonation. Chemosphere 77 214-221.

GALINDO C, JACQUES P and KALT A (2001) Photooxidation of phenylazonaphthol $\mathrm{AO} 20$ on $\mathrm{TiO}_{2}$ : kinetic and mechanistic investigations. Chemosphere 45 997-1005.

GALINDO C and KALT A (1998) UV- $\mathrm{H}_{2} \mathrm{O}_{2}$ oxidation of monoazo dyes in aqueous media: a kinetic study. Dyes Pigm. 40 27-35.

GHODBANE H and HAMDAOUI O (2010) Decolourisation of antraquinonic dye C.I. Acid Blue 25, in aqueous solution by direct UV irridation, UV/H2O2 and UV/Fe(II) processes. Chem. Eng. J. 160 226-231.

GUIMARAES JR, MANIERO MG and DE ARAUJO RN (2012) A comparative study on the degradation of RB-19 dye in an aqueous medium by advanced oxidation processes. J. Environ. Manage. 110 33-39.

HE Z, LIN L, SONG S, XIA M, XU L, YING H and CHEN J (2008) Mineralization of C.I. Reactive Blue 19 by ozonation combined with sonolysis: Performance optimization and degradation mechanism. Sep. Purif. Technol. 62 376-381.

JAYSONA GG, PARSONS BJ and SWALLOW AJ (1973) Some simple, highly reactive, inorganic chlorine derivatives in aqueous solution. J. Chem. Soc. Faraday Trans. 69 1597-1607.
JIANG PY, KATSUMURA Y, NAGAISHI R, DOMAE M, ISHIKAWA K, ISHIGURE K and YOSHIDA Y (1992) Pulse radiolysis study of concentrated sulfuric acid solutions. J. Chem. Soc. Faraday Trans. 88 (12) 1653-1658.

KAMPYLI V, PHILLIPS DAS and RENFREW AHM (2004) Reactive dyes containing a 4-m carboxypyridinium-1,3,5- triazine-2-oxide reactive group: exhaust dyeing of cotton under alkaline and neutral fixation conditions. Dyes Pigm. 61 165-175.

KATSUMURA Y, JIANG PY, NAGAISHI R, OISHI T and ISHIGURE K (1991) Pulse radiolysis study of aqueous nitric acid solutions. Formation mechanism, yield, and reactivtty of $\mathrm{NO}_{3}$ radical. J. Phys Chem. 95 4435-4443.

KIM TH, PARK C, LEE J, SHIN EB and KIM S (2002) Pilot scale treatment of textile wastewater by combined process (fluidized biofilm process-chemical coagulation-electrochemical oxidation). Water Res. 36 3979-3988.

KUNZ A, MANSILLA H and DURAN N (2002) A degradation and toxicity study of three textile reactive dyes by ozone. Environ. Technol. 23 911-918.

KURBUST, SLOKAR YM and LE MARECHAL AM (2002) The study of effect of variables on $\mathrm{H}_{2} \mathrm{O}_{2} / \mathrm{UV}$ decoloration of vinylsulphone dye: part II. Dyes Pigm. 54 67-78.

LEA J and ADESINA AA (1998) The photo-oxidative degradation of sodium dodecyl sulfate in aerated aqueous $\mathrm{TiO}_{2}$ suspension. J. Photochem. Photobiol. A 118 111-122.

LERGINI O, OLIVEROS E and BRAUN AM (1993) Photochemical processes for water treatment. Chem. Rev. 93 671-698.

LIAO CH, KANG SF and WU FA (2001) Hydroxil radical scavenging role of chloride and bicarbonate ions in the $\mathrm{UV} / \mathrm{H}_{2} \mathrm{O}_{2}$ process. Chemosphere 44 1193-1200.

LIZAMA C, FREER J, BAEZA J and MANSILLA H (2002) Optimized photodegradation of Reactive Blue 19 on $\mathrm{TiO}_{2}$ and $\mathrm{ZnO}$ suspensions. Catal.Today 76 235-246.

MARUTHAMUTHU P and NETA P (1978) Phosphate radicals. Spectra, acid-base equilibria, and reactions with inorganic compounds. J. Phys. Chem. $82710-713$.

MILLS A, DAVIS R and WORSLEY D (1993) Water purification by semiconductor photocatalysis. Chem. Soc. Rev. 22 417-434.

MITROVIC J, RADOVIC M, BOJIC D, ANDJELKOVIC T, PURENOVIC M and BOJIC A (2012) Decolourisation of textile azo dye Reactive Orange 16 with $\mathrm{UV} / \mathrm{H}_{2} \mathrm{O}_{2}$ process. J. Serb. Chem. Soc. 77 465-481.

MURUGANANDHAM M and SWAMINATHAN M (2004) Photochemical oxidation of reactive azo dye with $\mathrm{UV}-\mathrm{H}_{2} \mathrm{O}_{2}$ process. Dyes Pigm. 62 269-275.

RAJKUMAR D, SONG BJ and KIM JG (2007) Electrochemical degradation of Reactive Blue 19 in chloride medium for the treatment of textile dyeing wastewater with identification of intermediate compounds. Dyes Pigm. 72 1-7.

REZAEE A, GHANEIAN MT, HASHEMIAN SJ, MOUSSAVI G, KHAVANIN A and GHANIZADEH G (2008) Decolourisation of Reactive Blue 19 from textile wastewater by $\mathrm{UV} / \mathrm{H}_{2} \mathrm{O}_{2}$ process. J. Applied Sci. 8 (6) 1108-1112.

SAQUIB M and MUNEER M (2002) Semiconductor mediated photocatalysed degradation of an antraquinone dye, Remazol Brilliant Blue R Under sunlight and artificial light source. Dyes Pigm. 53 237-249.

SONG S, YAO J, HE Z, QIU J and CHEN J (2008) Effect of operational parameters on the decolourisation of C.I. Reactive Blue 19 in aqueous solution by ozone-enhanced electrocoagulation. J. Hazardous Mater. 152 204-210.

WANG S (2008) A comparative study of Fenton and Fenton-like reaction kinetics in decolourisation of wastewater. Dyes Pigm. 76 33-50.

XU B, GAO N, CHENG H, XIA S, RUI M and ZHAO D (2009) Oxidative degradation of dimethyl phthalate (DMP) by $\mathrm{UV} / \mathrm{H}_{2} \mathrm{O}_{2}$ process. J. Hazardous Mater. 162 954-959.

ZOLLINGER H (2003) Color Chemistry: Syntheses, Properties and Applications of Organic Dyes and Pigments. Wiley, Germany.

http://dx.doi.org/10.4314/wsa.v40i3.21

Available on website http://www.wrc.org.za

ISSN 0378-4738 (Print) = Water SA Vol. 40 No. 3 July 2014

ISSN 1816-7950 (On-line) = Water SA Vol. 40 No. 3 July 2014 
http://dx.doi.org/10.4314/wsa.v40i3.21 Available on website http://www.wrc.org.za

ISSN 0378-4738 (Print) $=$ Water SA Vol. 40 No. 3 July 2014 ISSN 1816-7950 (On-line) = Water SA Vol. 40 No. 3 July 2014 